\title{
Atomic Force Microscope Surface Roughness Analysis of Surface Treated Ceramics
}

\author{
Amna Salem ${ }^{1 *}$, Cherif Mohsen ${ }^{2}$ \\ ${ }^{1}$ Department of Fixed Prosthodontics, Faculty of Dentistry, Assiut University, Assiut, Egypt; ${ }^{2}$ Department of Fixed Prosthodontics, \\ Faculty of Dentistry, Minia University, Minia, Egypt
}

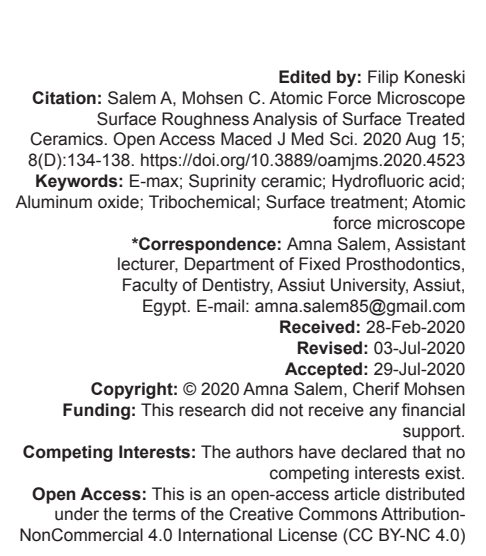

Introduction

All-ceramic restorations are favorable for dentists and patients because of their esthetic and durability in conservative tooth preparations [1].

Nowadays, ceramics are mainly lithium disilicate (LD) -based computer-aided design; computer-aided manufacturing (CAD) blocks [2].

Recently, a new material, zirconia-reinforced lithium silicate ceramic, was introduced to the market under the argument that zirconia could act as a crystal phase that can reinforce the material, that is, avoid crack propagation. This material which can be etched with hydrofluoric acid (HF) as a ceramic matrix is predominantly glass with zirconia $(8 \%-12 \%)$ [3].

Achieving adhesion between a luting agent and a ceramic surface requires surface pretreatment. A strong resin bond depends on chemical bonding and micromechanical interlocking to the ceramic surface, which requires surface cleaning and roughening for adequate activation of the surface [4].

To achieve this bond, the ceramic surface may be modified mechanically, chemically, or by laser to promote surface roughness and/or reactivity of the porcelain to the luting agent.

Air abrasion with aluminum oxide particles using a chairside device is one of the techniques of surface treatment to increase micromechanical retention [5].

The use of hydrofluoric acid etching of ceramic surface resulted in an alternative surface by selectively etching the glass matrix [6]. Roughening of the surface by tribochemical surface treatment is considered a reliable method using aluminum oxide particles with silica coating and silane application [2].

Atomic force microscopy (AFM) characterizes the surface topography of tested materials with rear atomic resolution, three dimensional evaluations of the specimens using a very small probe that follows the profile of the surface [7]. Quantitative information also can be recorded without complicated steps such as staining, dehydration, film covering, or a vacuum environment [8].

The aim of this study is to evaluate surface roughness of two types of ceramic using different techniques of surface treatment. 


\section{Materials and Methods}

Two types of ceramic used in this study LD (IPS e-max, CAD Ivoclar Vivadent AG, Schaan, Liechtenstein, USA) and hybrid ceramic (HC) and zirconia-reinforced lithium silicate (VITA Suprinity pc, VITA Zahn fabric, Bad Säckingen, Germany) were shown in Table 1.

Table 1: The chemical composition of IPS e. max CAD and VITA Suprinity pc

\begin{tabular}{|c|c|c|c|}
\hline Materials & Chemical composition & Manufacturer & Description \\
\hline $\begin{array}{l}\text { IPS e. } \\
\max \circledast \mathrm{CAD}\end{array}$ & $\begin{array}{l}\text { 57-80\%Sio211- } \\
\text { 19\%Li2o0-13\%K2o0- } \\
\text { 11\%P2o50-8\%Zro2- } \\
\text { Zno0-5\%Al2o30-5\%Mgo- } \\
\text { colouring oxides }\end{array}$ & $\begin{array}{l}\text { (Ivoclar- } \\
\text { Vivadent, } \\
\text { Liechtenstein, } \\
\text { Schaan }\end{array}$ & $\begin{array}{l}\text { Lithium disilicate LS2 glass } \\
\text { ceramic }\end{array}$ \\
\hline $\begin{array}{l}\text { Vita } \\
\text { Suprinity® }\end{array}$ & $\begin{array}{l}\text { 56-64\%Sio25-21\%Li2o1- } \\
4 \% \text { K2o3-8\%P2o58- } \\
12 \% \text { Zro20-4\%Ceo20- } \\
6 \% \text { pigments }\end{array}$ & $\begin{array}{l}\text { (Vita Zahnfabrik, } \\
\text { Bad Säckingen, } \\
\text { Germany) }\end{array}$ & $\begin{array}{l}\text { Pre-sintered lithium silicate/ } \\
\text { phosphate glass-ceramic } \\
\text { zirconia-reinforced ( } 10 \% \text { by } \\
\text { weight) lithium silicate ceramic }\end{array}$ \\
\hline
\end{tabular}

\section{Preparation of ceramic samples}

One hundred sixty disks $(5 \mathrm{~mm}$ in diameter and $2 \mathrm{~mm}$ thick) were fabricated of the two types of ceramic eighty disks of L.D and eighty disks of H.C, then disks were crystallized in a furnace at a prescribed temperature according to manufacturer's instructions.

Disks were then randomly subdivided into four groups according to the surface treatment $(n=20)$. L.D I: Control group without any surface treatment. L.D II: Using $\left(\mathrm{AL}_{2} \mathrm{O}_{3}\right)$ particles size $50 \mu \mathrm{m}$. L.D III: Hydrofluoric acid etching. L.D IV: Tribochemical surface treatment. $\mathrm{HC}$ disks were randomly subdivided into four groups according to surface treatments $(n=20)$. H.C I: Control group without any surface treatment. H.C II: Air abrasion using $\left(\mathrm{AL}_{2} \mathrm{O}_{3}\right)$ particles size $50 \mu \mathrm{m}$. H.C III: Hydrofluoric acid etching. H.C IV: Tribochemical surface treatment.

Air abrasion was done using aluminum oxide particles $\mathrm{Al}_{2} \mathrm{O}_{3}$ size $50 \mu \mathrm{m}$ (Korox, Bego, Bremen, Germany) using a chairside sandblasting device (prep star, Danville Instrument, CA, USA) at a pressure of 2.8 bars, from a distance of $10 \mathrm{~mm}$, perpendicular to the treated surface for $20 \mathrm{~s}$.

Hydrofluoric acid etching of the samples was done using $(9.5 \%)$ buffered hydrofluoric acid gel, Bisco, Schaumburg, U.S.A, for $20 \mathrm{~s}$, then rinsed with distilled water for one minute, ultrasonically cleaned in distilled water for one minute and finally dried with compressed oil-free water/air spray.

Tribochemical surface treatment was done by first cleaning the treated surface with $110 \mu \mathrm{m}$ aluminum oxide sand (Korox, Bego, Bremen, Germany) at a pressure of 2.8 bars, from a distance of $10 \mathrm{~mm}$, perpendicular to the treated surface for $15 \mathrm{~s}$. Then, the surface was micro-blasted with silica-modified aluminum oxide using a chairside sandblasting device (prep star, Danville instrument, CA, USA) (110 $\mu \mathrm{m}$ $\mathrm{Al}_{2} \mathrm{O}_{3}$ and $30 \mu \mathrm{m} \mathrm{SiO}{ }_{2}$ ) at a pressure of 2.8 bars, from a distance of $10 \mathrm{~mm}$, perpendicular to the treated surface for $15 \mathrm{~s}$. The next step was silanization with (Rely $X$ ceramic primer, 3M ESPE, USA) for $5 \mathrm{~min}$. Apply silane coupling agent to the treated ceramic surface then, gently oil-free air was blown across the surface.

\section{AFM}

Surface roughness and topography were measured by AFM (ThermoMicroscope, Bruker, Santa Barbara, CA, USA), before the AFM analysis, the treated surfaces of all samples were cleaned with $70 \%$ alcohol, and allowed to dry at room temperature.

AFM was operated in the contact mode with the treated surface of all samples at room temperature. Cantilever (radius of $10 \mathrm{~nm}$ ) was in constant contact with the surface of the samples. Movement of cantilever that resulted from changing forces acting between the cantilever and the contact surface of the sample was detected by the sensor. The process was measured by software all time and monitored by bending the cantilever over the tops of unevenness surface roughness. 3D surface topographies of the different prepared samples were precisely reconstructed. $20 \mu \mathrm{m} \times 20 \mu \mathrm{m}$ digital images were slowly scanned and recorded.

\section{Statistical analysis}

The results were collected, tabulated, and statistically analyzed using SPSS program (Statistical Package for Social Sciences) software version 25. Statistical analysis was done by one-way ANOVA and Tukey's post hoc test with significance level 0.05 .

\section{Results}

AFM comparative display of roughness parameter (mean $\mathrm{Ra}$; arithmetic average roughness) under different surface treatments of (IPS e. max CAD) and HC (VITA Suprinity pc) ceramic was shown in Table 2.

Statistical analyses of roughness of both types of ceramic were shown in Figures 1 and 2. From

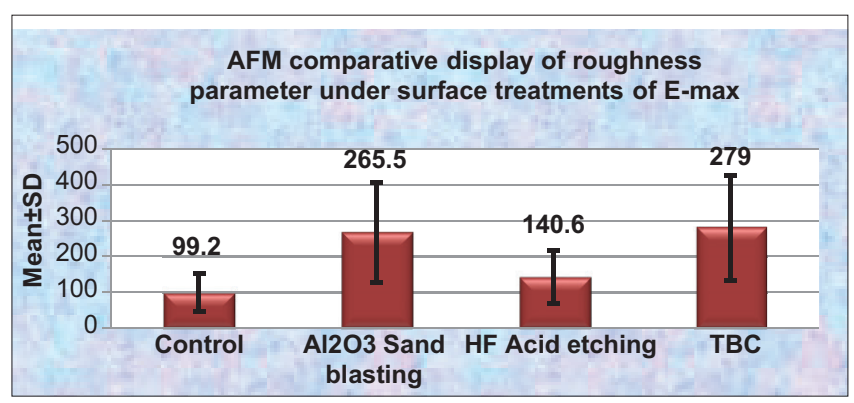

Figure 1: Statistical analyses of roughness of lithium disilicate ceramic (IPS e. max CAD) 
Table 2: Atomic force microscope comparative display of roughness parameter (mean Ra; arithmetic average roughness) under different surface treatments of lithium disilicate (E-max) and hybrid ceramic (Suprinity)

\begin{tabular}{|c|c|c|c|c|c|c|c|}
\hline $\begin{array}{l}\text { Type of ceramic/ } \\
\text { type of treatment }\end{array}$ & $\begin{array}{l}(\mathrm{l}) \\
\text { Control } \\
(n=20)\end{array}$ & $\begin{array}{l}\text { (II) } \\
\text { Air abrasion } \\
(\mathrm{n}=20)\end{array}$ & $\begin{array}{l}\text { (III) } \\
\mathrm{HF} \\
(\mathrm{n}=20)\end{array}$ & $\begin{array}{l}(\mathrm{IV}) \\
\text { TBC } \\
(\mathrm{n}=20)\end{array}$ & $p$ value & & \\
\hline Lithium disilicate & & & & & $0.049^{*}$ & & \\
\hline Range & $33-165.3$ & $88.5-442.5$ & $46.8-234.3$ & $93-464.8$ & | versus || & | versus ||| & I versus IV \\
\hline Mean \pm SD & $99.2 \pm 52.3$ & $265.5 \pm 140$ & $140.6 \pm 74$ & $279 \pm 147$ & $\begin{array}{l}0.124 \\
\text { II versus III } \\
0.320 \\
0.038^{*}\end{array}$ & $\begin{array}{l}0.934 \\
\text { II versus IV } \\
0.997\end{array}$ & $\begin{array}{l}0.088 \\
\text { III versus IV } \\
0.241\end{array}$ \\
\hline Range & $26-130$ & $68.2-340.8$ & $45.4-226.8$ & $90-449.6$ & | versus || & | versus ||| & I versus IV \\
\hline Mean \pm SD & $78 \pm 41$ & $204.5 \pm 107.7$ & $136 \pm 71.7$ & $269.8 \pm 142.2$ & $\begin{array}{l}0.217 \\
\text { II versus III } \\
0.695\end{array}$ & $\begin{array}{l}0.788 \\
\text { II versus IV } \\
0.723\end{array}$ & $\begin{array}{l}0.033^{*} \\
\text { III versus IV } \\
0.180\end{array}$ \\
\hline
\end{tabular}

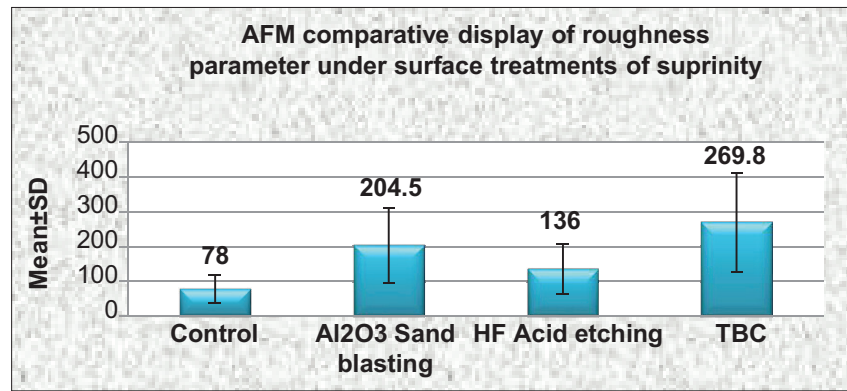

Figure 2: Statistical analyses of roughness of hybrid ceramic (VITA Suprinity $p c)$

results that had been presented in Table 2, it can be said that the lowest values of roughness parameters were for H.C I (78.11 $\pm 41 \mathrm{~nm})$ followed by L.D I (99.2 \pm $52 \mathrm{~nm})$ while the highest values were for L.D IV (279.8 $\pm 147 \mathrm{~nm})$ followed by H.C IV $(269.8 \pm 142 \mathrm{~nm})$ then L.D II $(265.5 \pm 140 \mathrm{~nm})$ followed by H.C II (204.5 \pm $107 \mathrm{~nm})$ then L.D III $(140.6 \pm 74 \mathrm{~nm})$ and finally H.C III $(136 \pm 71.7 \mathrm{~nm})$. Different surface treatment techniques increased surface roughness significantly for both types of ceramic. AFM 3D and 2D images of surface-treated (IPS e. max CAD) ceramic with different techniques were presented in Figure 3a-d and AFM 3D and 2D images of (VITA Suprinity pc) ceramic with different techniques were presented in Figure 4a-d. Tribochemical groups showed a non-uniform pattern with distinct sharp projections dotted with pores. Aluminum oxide groups also showed a non-uniform pattern but less distinct than tribochemical groups. Moderate irregularities with peaks and valleys with less roughness showed in HF acid groups. Acid-etched surfaces were slightly rougher with peaks and valleys higher and wider than those of control groups.

\section{Discussion}

Ceramic-based restorations have been luted with self-adhesive cements [9], [10]. Adhesive properties ofthesecements arebased on micromechanical retention that is made by acidic monomers that demineralize and infiltrate the tooth substrate. Fitting surfaces of ceramic restoration require surface pretreatment such as acidic

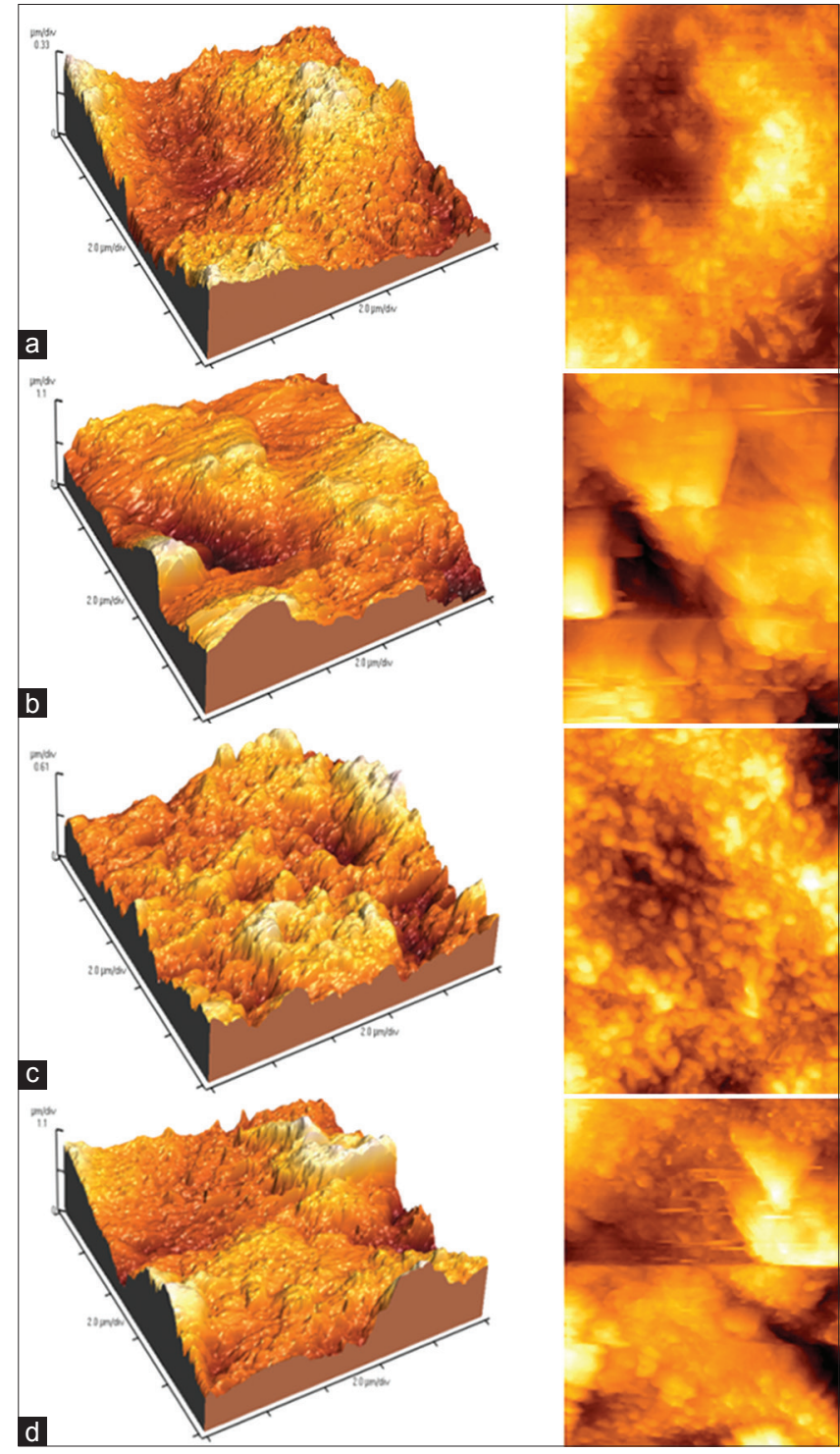

Figure 3: (a) 3D topography and $2 D$ view of lithium disilicate (L.D) I, (b) $3 D$ topography and $2 D$ view of $L . D I I$, (c) $3 D$ topography and $2 D$ view of L.D III, (d) $3 D$ topography and $2 D$ view of L.D IV

etching, air abrasion, or tribochemical silica coating, to produce micromechanical retention [10], [11], [12].

The null hypothesis of this study was accepted; science air abrasion, acid etching, and tribochemical surface treatments significantly increased the surface roughness of both types of ceramic compared to control groups of each type. 


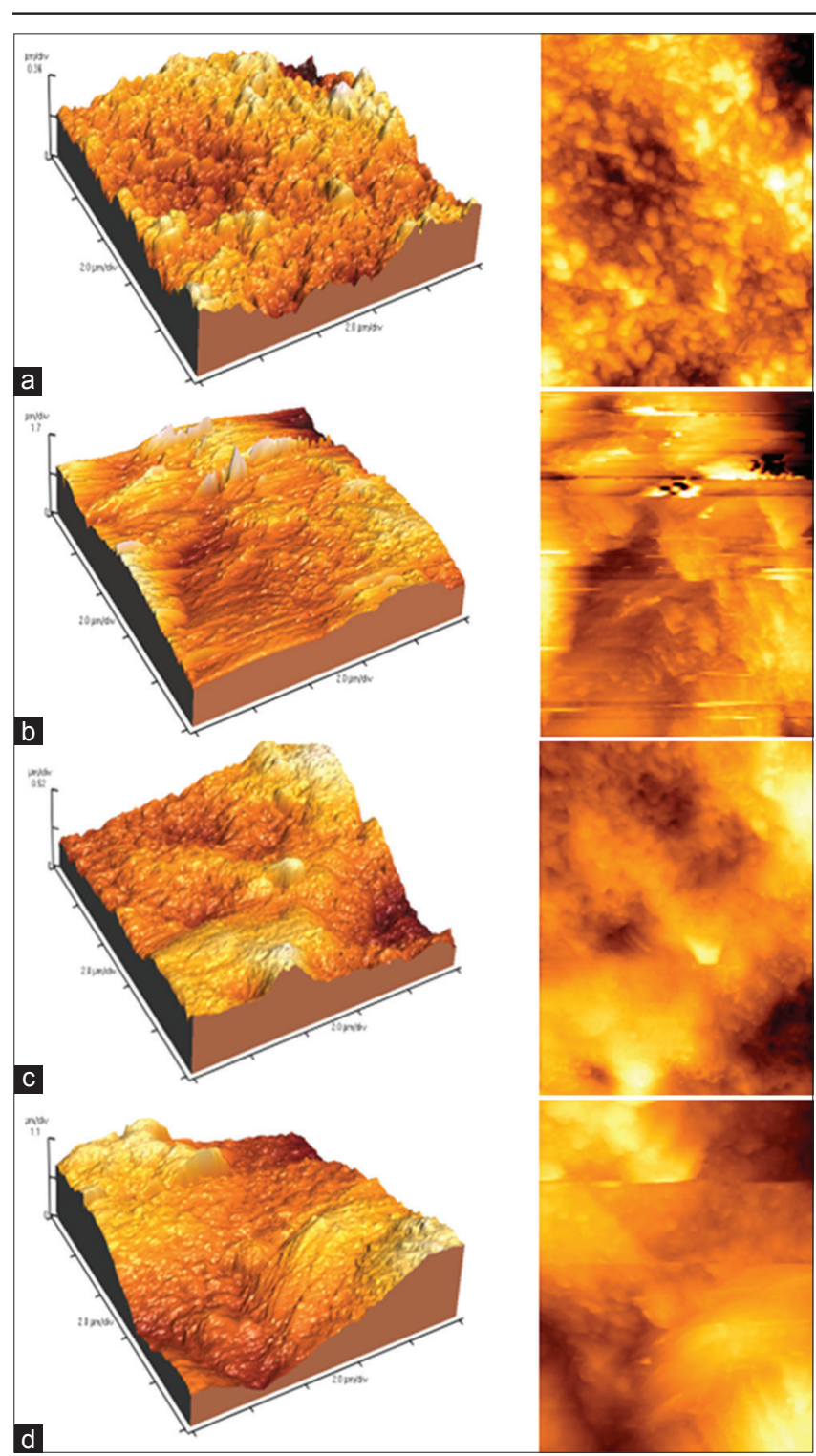

Figure 4: (a) 3D topography and 2D view of H.D I, (b) 3D topography and $2 D$ view of H.D II, (c) $3 D$ topography and $2 D$ view of H.D III, (d) $3 D$ topography and $2 D$ view of H.D IV

Using of AFM as a nano-characterization tool to analyze different organic and artificial dental surfaces [13]. AFM was used in different dental investigations focused in mechanical, chemical, and structure characterization of dentine substrate [14]. AFM was used in measuring of surface adhesion force and hardness of graphene on NiTi alloy coating [15]. Surface adhesion analysis, observation of collagen network, studying properties of bacterial cells, and characterization of dental restorative composite are different uses of AFM in dentistry [16].

One of the most common limitations of AFM is that the single scan image size $(150 \mu \mathrm{m} \times 150 \mu \mathrm{m})$. Slow scan time is another limitation which leads to sample thermal drift. Images of AFM affected by piezoelectric material and cross-talk between the three-axis $X, Y, Z$ that need software enhancement and filtering. Various image artifacts can be observed, but it can be reduced.
Furthermore, steep walls or overhangs cannot be measured [17].

Micromechanical retention was achieved using pure aluminum oxide $50 \mu \mathrm{m}$ grain-sized particles. Roughening the surface increases the bonding area and wettability of the ceramic with resin cements [18]. Söderholm and Shang [19] found that air abrasion was the most effective surface treatment for In-Ceram Alumina ceramic. Dilber et al. [8] stated that air abrasion resulted insufficient bond strength. However, excessive air abrasion causes chipping or loss of ceramic material and is not recommended for roughening of silica-based and field spathic ceramic [20], [21].

Tribochemical involves chemical bonds by applying kinetic energy in the form of sandblasting, without any application of additional heat or light. Applying silica on the surface and finally adding silane to the surface, which bonds chemically to resin cement as roughening the surface, improve the spread of silane coupling agent [22]. Silane is bifunctional organic compound that used to increase the chemical, physical, and mechanical adhesion through the creation of a chemical covalent siloxane bond ( $\mathrm{Si}-\mathrm{O}-\mathrm{Si}$ ) with ceramic surface hydroxyl groups [23].

Sato et al. [2] found that surface roughness was significantly increased using $\mathrm{CJ}$ silica coating and HF acid etching in comparison to the control group. Ersu et al. [23] demonstrated that air abrasion provides a rougher surface than $\mathrm{HF}$ and control group, which is in agreement with our study. HF acid dissolved glossy components of ceramics and induced micropores, thereby facilitating penetration of the resin into etched ceramic surface [20], [23]. Previous studies [24], [25] found that $\mathrm{HF}+$ silane was the most effective ceramic treatment, but not always significantly better than other types of treatment that included roughening and silane application.

Hazardous effect of HF acid etching was wellrecognized in vivo: It was irritant to soft tissue. Szep et al. [26] found that HF acid precipitates of fluoride deposits on surface of tooth structure which decreases bonding interaction. Most restorations that depend on adhesive bonding are etched in lab before being cemented in mouth. Then, they are rinsed in water and applying neutralizing gel is used to decrease any harmful risk. Proper bond strength between ceramic and tooth is depended on different modalities of surface treatments that give surface roughness on LD and HCs. There were some limitations in this study. Only two types of ceramic (LD and hybrid) were evaluated. Differences of compositions of a different ceramic material may affect bond strength and surface texture of ceramics and resin cements. Furthermore, different concentrations of $\mathrm{HF}$ acid and application periods have not been evaluated. Laser surface etching was not being tested in this study. 


\section{Conclusion}

Different surface treatments increased surface roughness significantly for IPS e.max CAD and VITA Suprinity pc ceramic materials.

\section{References}

1. Özcan M, Nijhuis $H$, Valandro LF. Effect of various surface conditioning methods on the adhesion of dual-cure resin cement with MDP functional monomer to zirconia after thermal aging. Dent Mater J. 2008;27(1):99-104. https://doi.org/10.4012/ dmj.27.99

PMid:18309618

2. Sato TP, Anami LC, Melo RM, Valandro LF, Bottino MA. Effects of surface treatments on the bond strength between resin cement and a new zirconia-reinforced lithium silicate ceramic. Oper Dent. 2016;41(2):284-92. https://doi.org/10.2341/14-357-I PMid:26652019

3. Özdemir H, Aladağ Lí. Effect of different surface treatments on bond strength of different resin cements to lithium disilicate glass ceramic: An in vitro study. Biotechnol Biotechnol Equip. 2017;31(4):815-20. https://doi.org/10.1080/13102818.2017.133 4589

4. Borges GA, SophrAM, De Goes MF, Sobrinho LC, Chan DC. Effect of etching and airborne particle abrasion on the microstructure of different dental ceramics. J Prosthet Dent. 2003;89(5):47988. https://doi.org/10.1016/s0022-3913(02)52704-9 PMid:12806326

5. Plueddemann EP. Adhesion through silane coupling agents. $J$ Adhes. 1970;2(3):184-201.

6. Wood DJ, Bubb NL, Millar BJ, Dunne SM. Preliminary investigation of a novel retentive system for hydrofluoric acid etch-resistant dental ceramics. J Prosthet Dent. 1997;78(3):27580. https://doi.org/10.1016/s0022-3913(97)70026-x

7. De Freitas AC, Espejo LC, Botta SB, De Sa Teixeira F, Luz MA, Garone-Netto N, et al. AFM analysis of bleaching effects on dental enamel microtopography. Appl Surf Sci. 2010;256(9):2915-9. https://doi.org/10.1016/j.apsusc.2009.11.050

8. Dilber E, Yavuz T, Kara HB, Ozturk AN. Comparison of the effects of surface treatments on roughness of two ceramic systems. Photomed Laser Surg. 2012;30(6):308-14. https://doi. org/10.1089/pho.2011.3153

PMid:22506513

9. Sanches RP, Otani C, Damião AJ, Miyakawa W. AFM characterization of bovine enamel and dentine after acidetching. Micron. 2009;40(4):502-6. https://doi.org/10.1016/j. micron.2008.12.001

10. De Oyagüe RC, Monticelli F, Toledano M, Osorio E, Ferrari M, Osorio R. Influence of surface treatments and resin cement selection on bonding to densely-sintered zirconium-oxide ceramic. Dent Mater. 2009;25(2):172-9. https://doi.org/10.1016/j. dental.2008.05.012

PMid: 18620746

11. Osorio E, Toledano M, Da Silveira BL, Osorio R. Effect of different surface treatments on In-Ceram Alumina roughness. An AFM study. J Dent. 2010;38(2):118-22. https://doi.org/10.1016/j. jdent.2009.09.010

12. Sorensen JA, Engelman MJ, Torres TJ, Avera SP. Shear bond strength of composite resin to porcelain. Int $\mathrm{J}$ Prosthodont.
1991;4(1):17-23.

PMid:2012666

13. Sharma S, Cross SE, Hsueh C, Wali RP, Stieg AZ, Gimzewski JK. Nanocharacterization in dentistry. Int J Mol Sci. 2010;11(6):2523-45. https://doi.org/10.3390/ijms11062523 PMid:20640166

14. Cassinelli C, Morra M. Atomic force microscopy studies of the interaction of a dentin adhesive with tooth hard tissue. $J$ Biomed Mat Res. 1994;28(12):1427-31. https://doi.org/10.1002/ jbm.820281207

15. Rokaya D, Srimaneepong V, Qin J, Thunyakitpisal $P$, Siraleartmukul K. Surface adhesion properties and cytotoxicity of graphene oxide coatings and graphene oxide/silver nanocomposite coatings on biomedical NiTi alloy. Sci Adv Mat. 2019;11(10):1474-87. https://doi.org/10.1166/sam.2019.3536

16. Yang H. Atomic Force Microscopy (AFM): Principles, Modes of Operation and Limitations. New York: Nova Science Publishers; 2014.

17. Smith DP. Limits of force microscopy. Rev Sci Instrum. 1995;66(5):3191-5.

18. Kara HB, Dilber E, Koc O, Ozturk AN, Bulbul M. Effect of different surface treatments on roughness of IPS Empress 2 ceramic. Lasers Med Sci. 2012;27(2):267-72. https://doi.org/10.1007/ s10103-010-0860-3

PMid:21110057

19. Söderholm KJ, Shang SW. Molecular orientation of silane at the surface of colloidal silica. J Dent Res. 1993;72:1050-4. https:// doi.org/10.1177/00220345930720061001 PMid:8388415

20. Blatz MB, Sadan A, Kern M. Resin-ceramic bonding: A review of the literature. J Prosthet Dent. 2003;89(3):268-74 PMid:12644802

21. Kern M, Thompson VP. Sandblasting and silica coating of a glassinfiltratedaluminaceramic:Volumeloss, morphology, and changes in the surface composition. J Prosthet Dent. 1994;71(5):453-61. https://doi.org/10.1016/0022-3913(94)90182-1

PMid:8006839

22. Heikkinen TT, Lassila LV, Matinlinna JP, Vallittu PK. Effect of operating air pressure on tribochemical silicacoating. Acta Odontol Scand. 2007;65(4):241-8. https://doi. org/10.1080/00016350701459753 PMid: 17762988

23. Ersu B, Yuzugullu B, Yazici AR, Canay S. Surface roughness and bond strengths of glass-infiltrated alumina-ceramics prepared using various surface treatments. J Dent. 2009;37(11):848-56. https://doi.org/10.1016/j.jdent.2009.06.017 PMid:19616883

24. Baratto SS, Spina DR, Gonzaga CC, Cunha LF Furuse AY, Filho FB, et al. Silanated surface treatment: Effects on the bond strength to lithium disilicate glassceramic. Braz Dent J. 2015;26(5):474-7. https://doi. org/10.1590/0103-6440201300354 PMid:26647931

25. Kamada K, Yoshida K, Atsuta M. Effect of ceramic surface treatments on the bond of four resin luting agents to a ceramic material. J Prosthet Dent. 1998;79(5):508-13. https://doi. org/10.1016/s0022-3913(98)70170-2 PMid:9597602

26. Szep S, Gerhardt T, Gockel HW, Ruppel M, Metzeltin D, Heidemann D. In vitro dentinal surface reaction of $9.5 \%$ buffered hydrofluoric acid in repair of ceramic restorations: A scanning electron microscopic investigation. J Prosthet Dent. 2000;83(6):668-74. https://doi.org/10.1016/ s0022-3913(00)70069-2

PMid:10842137 